EREM 76/3

Journal of Environmental Research, Engineering and Management Vol. 76 / No.3 / 2020 pp. 121-136 DOI 10.5755/j01.erem.76.3.24258

\section{Landscape Functional Zoning of Urban Protected Areas}

Received 2019/09

Accepted after revision 2020/08

rossef $h t t p: / / d x . d o i . o r g / 10.5755 / j 01 . e r e m .76 .3 .24258$

\title{
Landscape Functional Zoning of Urban Protected Areas
}

\author{
Havrylenko Olena*, Shyshchenko Petro, Tsyhanok Yevhen
}

Taras Shevchenko National University of Kyiv, 2A, Glushkov Prospekt, Kyiv, 03680 Ukraine

*Corresponding author: olena.geo@gmail.com

The article deals with the need to consider the territory landscape structure during the landscape functional zoning of urban protected areas (UPA) (by example of the Holosiyivskyi National Natural Park (NNP) in Kyiv). The study revealed the shortcomings of the UPA functional zoning procedure without applying a landscape approach, regardless of its importance for preventing nature management conflicts. According to the research goals, it is necessary to study the UPA landscape structure and transfer the functional zoning procedure to the landscape basis. Holosiyivskyi Forest, as one of the five massifs in Holosiyivskyi NNP, was chosen for the analysis. A landscape map was created and a landscape-functional zoning scheme of the Holosiyivskyi Forest territory was updated using field research findings, available digital maps and GIS tools. Moreover, the relief morphometric parameters were reflected in the digital model and a hypsometric map of Holosiyivskyi Forest was created on its basis. By providing maximum correspondence of the nature management structure in each functional zone with the existing landscape structure of the territory, traditional zoning turns into a landscape functional one. The study assessed the adverse impact of the urban environment on Holosiyivskyi Forest's natural landscapes. The research demonstrates the imperfection of Ukrainian nature conservation legislation, the absence of the Holosiyivskyi NNP land management project and the need to define the Park's true boundaries around its territory. Research findings are a basis for minimizing existing nature management conflicts, reducing the anthropogenic impact on the ecosystems, rationally controlling recreational flows, and planning anti-erosion and other activities to optimize functioning of protected areas in an urbanized environment.

Keywords: Urban protected areas, nature management conflicts, Holosiyivskyi National Natural Park, landscape functional zoning, buffer landscape functional zone. 


\section{Introduction}

More than half of the world's population lives in cities. The impact of urbanization on natural landscapes and those close to natural ones is ever increasing. To preserve these nature sites in cities, the crucial task is to intensify the protection of existing conservation areas and create new ones. These areas are a special "buffer" that mitigates the adverse impact of the urban environment on the natural surroundings. Urban protected areas (UPA) perform important functions. In particular, they provide ecosystem services, save rare species, and support the local economy by tourism revenues. The prime value of UPA is an access to open air recreation for many city residents who cannot visit similar places far from cities. This task is performed best by a multifunctional UPA with a high level of landscape and biological diversity. Instead, the implementation of basic UPA environmental and recreational functions is obstructed by the excessive anthropogenic pressure on its territory. Numerous nature management conflicts and insufficient public awareness of the status of these territories lead to degradation of landscapes, loss of biodiversity, intensification of hazardous processes and deterioration of the quality of provided ecosystem services.

UPA may belong to any of the six categories of protected areas approved by the International Union for Conservation of Nature (IUCN). They do not include regular parks with lawns, flower beds and sports grounds. UPA have much more visitors than similar facilities located far from inhabited settlements. The frequency of visits, which depends on UPA transport accessibility in the city, is also much higher. Protected areas in an urbanized environment are under a constant threat of city expansion and intensification of its development. Popular UPA suffer from vandalism, littering, waste dumping, light and noise pollution, frequent fires, air and water pollution, and introduction of invasive alien species (Trzyna, 2014).

Green space is essential in ensuring a sustainable urban development due to many environmental, recreational and economic benefits. Expanding urbanization brings to the forefront the key landscape planning tasks of building an effective urban ecological network and supporting a sustainable urban environment. A green space system is planned by analysing the landscape structure of environmental corridors. The improvement of the ecological network of urbanized landscapes is quantified by comparing the ecological network and the green space planning system (Haifeng et al., 2015). The substantial man-made burden has caused a radical transformation of UPA landscapes despite their conservation status. Preventing their further degradation calls for optimizing the functioning of the territories, with involvement of the landscape analysis. The main result of such analysis is a landscape map that reflects the actual picture of territory differentiation into natural complexes of different ranks (Havrylenko and Tsyhanok, 2018). Consequently, multifunctional protected areas, represented by national parks, should be preserved based on the results of landscape-ecological analysis, which account for the modern landscape structure and the landscape diversity of protected areas.

Some researchers point out the need to consider the landscape structure of the urbanized space when developing the concept of a "sustainable city". This primarily means optimizing the interaction of landscape architecture and urban planning (Deveikienè, 2018), creating nature protection zones in resort towns (Khoshtaria and Chachava, 2017), city green space planning (Veinberga and Zigmunde, 2016), etc. Many studies are devoted to differentiation of protected areas into functional zones. The original functional zoning method has also been used to substantiate the declaring of the Guadarrama Mountains in Spain as a National Park. Among other things, the zoning procedure has made allowance for the compatibility of land use with the "visual quality" of landscapes. To a certain extent, this means that a landscape approach is applied to the protected area zoning procedure. The rational nature of potential activities has been based on a multivariate analysis of the studied territory (Ruiz-Labourdette et al., 2010). Functional zoning is a part of the organizational planning of protected areas and an important tool for managing these territories. The allocation of optimal zones helps to prevent 
potential conflicts. For an effective siting of potential activities, it is suggested to account for the compatibility of land use with the main landscape characteristics (Hasti et al., 2016).

Studies devoted to the development of functional zoning of protected areas in the specific conditions of an urbanized environment are still few in number. In particular, a method of zoning process automation in the geoinformation environment based on forest management materials and field research is proposed. UPA functional zoning has been conducted based on the following series of thematic maps: land category, vegetation types, classes of land fire danger, and real estate development patterns (Filozof, 2010). The advantage of such a study is the creation of a geographical database that can serve as a monitoring and management tool for the territory in the future. However, ignoring the existing landscape structure of UPA is a significant drawback. Therefore, it is worthwhile to include a landscape analysis of the territory and an estimate of provided vital ecosystem services in the previously developed concepts of functional zone planning.

The purpose of the study is to substantiate the need to account for the landscape structure of the territory and to conduct landscape functional zoning (LFZ) of urban protected areas on its basis (by example of Holosiyivskyi Forest, one of the five massifs of the Holosiyivskyi National Natural Park (NNP) in Kyiv).

\section{Materials and methods}

The choice of Holosiyivskyi NNP in Kyiv is not accidental for the research. It is one of the few National Parks in the world located in a large city, and it represents the national network link of Ukraine's Nature Reserve Fund. Holosiyivskyi NNP was created in accordance with the Decree of the President of Ukraine of August 27, 2007, with the purpose of preservation, reproduction and rational exploitation of especially valuable natural complexes and sites of the Forest Steppe northern part, as well as for improvement of Kyiv's ecological state (Legislation, 2008). Another Presidential Decree of May 1, 2014, changed Holosiyivskyi
NNP boundaries by extending its territory to $6,462.62$ hectares (Legislation, 2014b). The Park is located in the southern and southwestern parts of Kyiv in the Holosiyivskyi District. The total area of the Park is 10,988.14 hectares, including 1,888.18 ha of land allotted to the Park Administration for general use (National, 2018). Holosiyivskyi NNP is subordinated to the Ministry of Ecology and Natural Resources of Ukraine.

Before its creation, the NNP territory had the status of the Holosiyivskyi Regional Landscape Park, which included the Lisnyky Botanical Reserve of national significance, as well as park sites of garden park art of national significance: Holosiyivskyi Forest and Maxym Rylskyi Holosiyivskyi Park. According to the physiographic zoning scheme of Ukraine (Marynych et al., 2003), the Holosiyivskyi NNP territory belongs to the Kyiv highland region of the Dniester-Dnipro Forest Steppe province and the Northern Dnipro terraced lowland region of the Left-Bank Dnipro province of the forest steppe landscape zone. To the north, the Park borders on the Kyiv Polissya region of the mixed forest zone. The Dnipro Valley divides the Dnipro Lowland and the Dnipro Highland where the Park's northern part is located. Holosiyivskyi NNP consists of several separated massifs (Fig. 1).

The Park's southern part (the Lisnyky stow and the lands to the south from the Koncha-Zaspa micro district) is limited by Stolychne Highway in the east, coincides with the border of Kyiv through the Mrygy hamlet on the south and west, and borders on Kalynove village on the north. The Bychok stow is located on both sides of the Stolychne Highway to the south from the Korchuvate micro district. The Svyatoshynskyi-Bilychanskyi forest massif is the northern part of the Park, which borders on such micro districts as Bilychi, Novobilychi, and Berkovets in the east. In the west, the boundary passes through the Irpin River floodplain. The Teremky stow borders on Glushkov Prospect and residential areas, and on agricultural lands in the southwest. Holosiyivskyi Forest, located in the central part of the Park, borders on the residential areas in the west, Holosiyivskyi Prospect in the northwest, the National Expo Centre of Ukraine in the east, and the Museum of Folk Architecture and Life of Ukraine in the south (National, 2018). 
Fig. 1. Territorial structure of Holosiyivskyi National Natural Park (According to National, 2018)

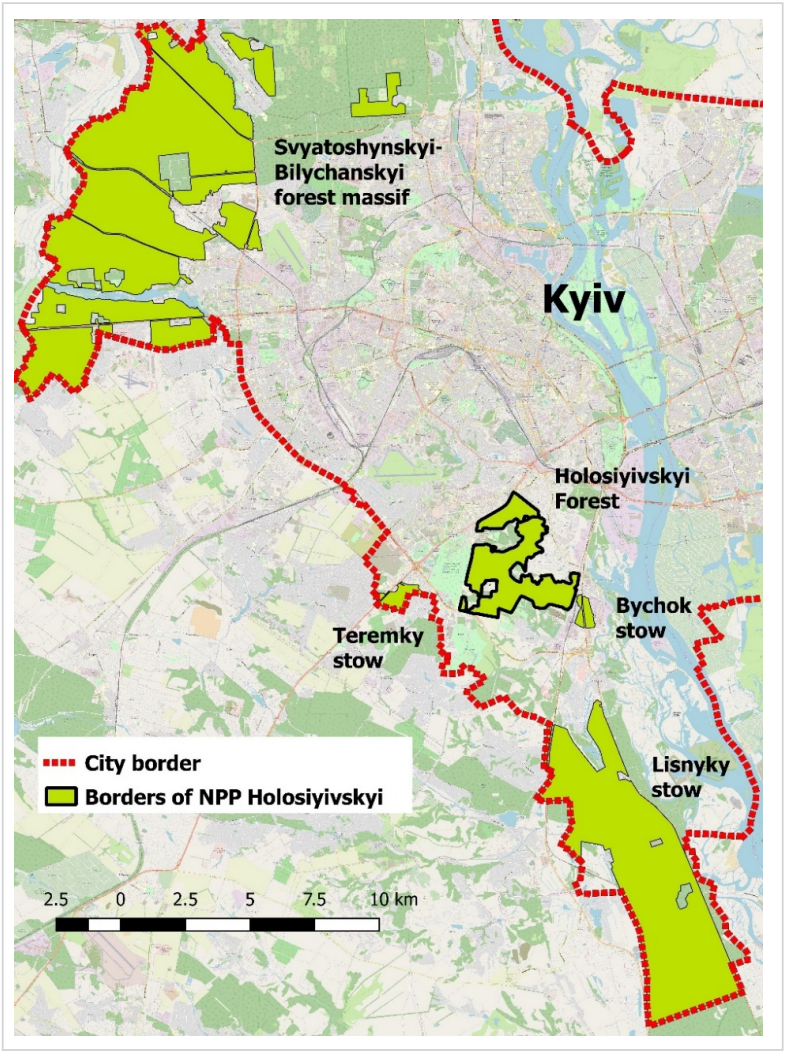

Effective LFZ is such a partitioning of protected areas when the nature management structure of each allocated zone fits the territory's existing landscape structure as much as possible. In other words, the basis of the zone's allocation is a landscape map and a map of the territory's current use, which are superimposed on one another. Each landscape functional zone is determined by the following main criteria: value of areas depending on the degree of their anthropogenic transformation, presence of biotopes with different biodiversity, habitats of rare flora and fauna species, nesting places of birds and wintering grounds of animals, historical and cultural heritage sites, and the recreational capacity and accessibility for visitors (Table 1).

LFZ aims to promote a rational organization of nature management with consideration of the following: natural, scientific, recreational, wellness, and historical and cultural values; the current geoecological
Table 1. Main criteria for allocation of landscape functional zones in Holosiyivskyi Forest

\begin{tabular}{l|l}
\multicolumn{1}{c|}{$\begin{array}{c}\text { Landscape } \\
\text { functional zone }\end{array}$} & \multicolumn{1}{c}{ Zoning criteria } \\
\hline Reserved & $\begin{array}{l}\text { Most valuable landscape complexes } \\
\text { unchanged by human activity; the } \\
\text { presence of rare species of flora and } \\
\text { fauna. }\end{array}$ \\
\hline Stationary recreation & $\begin{array}{l}\text { Landscape complexes, close to } \\
\text { natural ones, with a significant } \\
\text { aesthetic and recreational value; } \\
\text { accessibility for tourists. }\end{array}$ \\
\hline Economic & $\begin{array}{l}\text { The presence of a developed } \\
\text { recreational infrastructure and } \\
\text { landscape complexes with high } \\
\text { scenery diversity; convenient } \\
\text { transport accessibility. }\end{array}$ \\
\hline Buffer & $\begin{array}{l}\text { Landscape complexes transformed } \\
\text { most by anthropogenic activities } \\
\text { with low aesthetic-recreational } \\
\text { attractiveness; presence of industrial } \\
\text { buildings and structures. }\end{array}$ \\
\hline $\begin{array}{l}\text { Existing and potential nature } \\
\text { management conflicts and threats } \\
\text { to other zones from urban activities } \\
\text { (construction, road laying, dumping } \\
\text { of waste, etc.). }\end{array}$ \\
\hline
\end{tabular}

situation; and the possibilities of restoring the natural state of disturbed components of geosystems and observance of the environmental protection regime in the UPA and adjacent territories. SAGA GIS and QGIS software packages were used to create maps. The topographic basis is the digital map of the Holosiyivskyi district of Kyiv, scale 1:2000, with the following thematic layers: relief, vegetation, settlements, hydrological objects, and road network. The QGIS toolkit allows inventorying data on the distribution of valuable plant species or forest types, and identify potential threats from property developers, the transport infrastructure, or excessive recreational pressure. The source of additional information is analysis of Google images, previously created maps and field research. Since one of the principal factors in the formation of modern natural complexes is the relief, the landscape hypothesis map of Holosiyivskyi Forest was created 
based on the geomorphological structure of its territory. The Digital Elevation Model (DEM) was created to reflect the morphometric relief parameters (slopes exposure and steepness, density of erosion dissection). The hypsometric map of the Holosiyivskyi Forest massif was obtained following DEM filtration (Fig. 2).

The surface slope is an important morphometric parameter characterizing the elevation difference. Its value is calculated based on the filtered DEM fragment and visualized in generally accepted fixed ranges. Surface slope layers are also superimposed on the topographic base to reflect the intensity of the course of erosion and other exogenous processes on the slopes. Maps of the Holosiyivskyi Forest landscape structure and of the landscape functional zoning were created using this information and the QGIS toolkit.

Fig. 2. Hypsometric map of Holosiyivskyi Forest

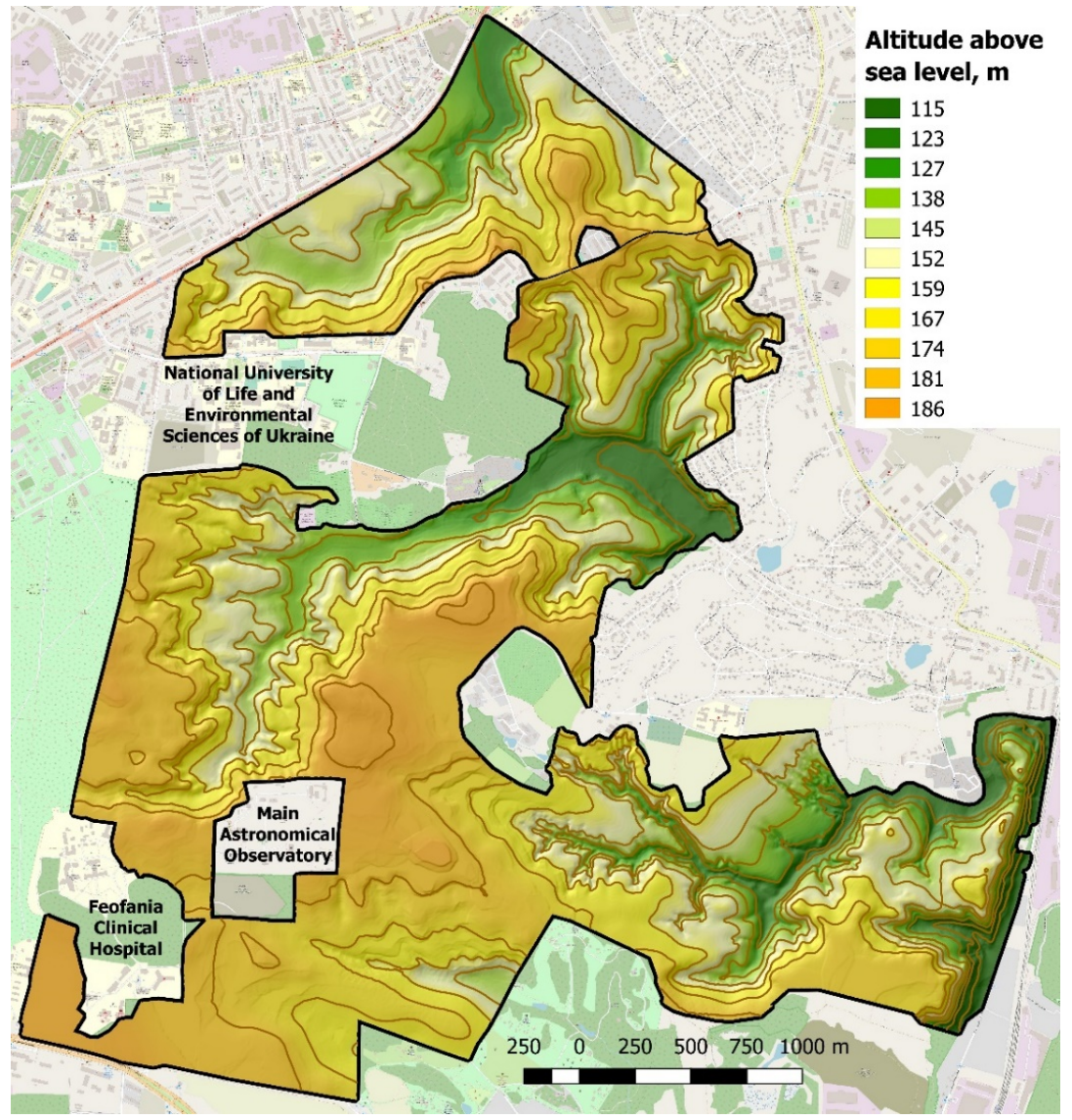

\section{Results and discussion}

The object of this study is the territory of the Holosiyivskyi Forest massif with an area of over 630 ha. The forest relief is conditioned largely by its location on the loess spurs of the Kyiv Plateau where plateau-like areas alternate with numerous erosion forms. There are three ravine and gully systems with the Horikhuvatskyi, Holosiyivskyi and Kytayivskyi streams as axes (Onyshchenko et al., 2016). The soil cover in the 
forest is monotonous. The elevations and slope peaks are dominated by grey and light-grey forest soils on loess sediments. In the watersheds, grey forest soils have a well-pronounced illuvial horizon, an acid reaction, and minor reserves of nutrients with a humus content of no more than $2.5 \%$. The light-grey forest soils have even a lesser thickness of the humus layer (20-22 cm) and a denser illuvial horizon (The Project, unpublished report).

Natural vegetation cenosis is represented by oak-hornbeam and derivative hornbeam forests, with oak, aspen and alder areas being retained from place to place. Forest stands are predominated by common hornbeam (Carpinus betulus L., 1753) and common oak (Quercus robur Sol., 1778). Oak trees, ousted by hornbeam in Holosiyivskyi Forest, are not renewed, but Norway maple and field maple are being intensively restored. The introduction of some woody and shrub species encouraged their wildness and penetration into natural forests. Large areas are also occupied by oak and pine cultures, with the grass cover being dominated by grass herbage and weeds. Black alder (Alnus glutinosa (L.) Gaerth., 1790) is widespread in stream valleys and in waterlogged areas and those preserved from flooding. There are rare species included in the Red Book of Ukraine (TRBU) and the IUCN Red List, such as the common snowdrop (Galanthus nivalis L., 1753), the fumewort (Corydalis cava (L.) Schweigg. \& Körte, 1811; Corydalis intermedia (L.) Merat, 1812; Corydalis solida (L.) Clairv., 1811), the two-leaf squill (Scilla bifolia L., 1753), the violet helleborine (Epipactis purpurata Sm., 1828), the broad-leaved helleborine (Epipactis helleborine (L.) Crantz, 1769), the martagon lily (Lilium martagon L., 1753), etc. (Onyshchenko et al., 2016).

The fauna variety in Holosiyivskyi Forest is represented by 80 species of vertebrate animals, including 52 bird species and 16 mammal species. In winter, the European otter (Lutra lutra L., 1758) included in TRBU can enter the forest territory. Rare species that have been retained are the stoat (Mustela erminea $\mathrm{L}$., 1758), the water shrew (Neomys anomalus Cabrera, 1907), the common pipistrelle (Pipistrellus pipistrellus Schreber, 1774), the stock dove (Columba oenas L., 1758), and the smooth snake (Coronella austriaca
Laurenti, 1768). The bird population is the richest: 47 bird species are nesting in Holosiyivskyi Forest. The species most vulnerable to the anthropogenic pressure are six species of predatory birds, of which only the northern goshawk (Accipiter gentilis L., 1758) and the common buzzard (Buteo buteo L., 1758) are permanently settled. The stock dove (Columba oenas L., 1758) has become very rare. The amphibian fauna in Holosiyivskyi Forest consists of ten species, and the fish population is only eight species (The Project, unpublished report).

\section{Threats and conflicts}

The specific location of Holosiyivskyi Forest in the metropolitan area causes a substantive transformation of natural landscapes. The ever-growing recreational pressure changes the vegetation and soil structure. The branching network of tourist paths causes the extinction of rare and typical plant species, and destruction of tree undergrowth and shrubs, i.e., irreversible modification of cenosis and biotopes. Due to trampling, the composition of species in some parts of the forest degrades, and some species even become extinct in plant communities. However, the populations of species resistant to trampling are increasing. The yellow archangel (Lamium galeobdolon L., 1759), the lesser celandine (Ficaria verna Huds., 1762), the finger sedge (Carex digitata L., 1753), and most grasses are among them. Fauna representatives, which inhabit parts of Holosiyivskyi Forest bordering on residential districts of Kyiv, are experiencing the biggest anthropogenic pressure. In recent decades, most species of bats, big predatory birds, rare species of owls and waders, several species of fish and insects have become extinct or they occur here sporadically. Clearing deadwood and trunks of fallen trees has led to the vanishing of the population of many forest stenobionts. Insects and other invertebrates pass the winter in the bark of fallen trees. In particular, the carpenter bee (Xylocopa valga Gerstaecker, 1872), which is a pollinator of many plant species, can completely disappear. Extinction of polypores leads to destruction of beetle habitats, including the darkling beetle (Tenebrionidae Latreille, 1802) and rove beetles (Staphylinidae). Due to the declining Corydalis population, the number of Clouded Apollo (Parnassius mnemosyne 
L., 1758) butterflies entered in the TRBU (The Project, unpublished report) is decreasing and this species is vanishing gradually.

The biggest recreational pressure is on meadow biotopes, marges and forest glades, where grass trampling leads to its complete depletion and soil compaction. Widespread bonfire lighting and territory littering causes the perishing of flowering plants, especially in early spring. This undermines the nutritive base for daytime lepidopterans and insect pollinators. Lighting bonfires in the lakeshore thickets burns out large areas around Holosiyiv lakes where most tourists gather. The location of the Holosiyivskyi Forest massif in a large city makes it close to industrial enterprises, residential and other buildings, and to an extensive traffic network. Due to urbanized environment pressure on forest natural landscapes, their structure becomes more primitive, established connections break down, and the diversity of species and landscape diversity is impoverished considerably. Synanthropization of some species occurs: due to hornbeam expansion to sites of oak-hornbeam forests, hornbeam forests are formed. The latter play an important role in purifying the atmospheric air of the city, but at the same time, they are affected adversely by industrial and automotive emissions.

Age-old oaks are one of the greatest scientific and nature conservation assets of oak-hornbeam forests in the Holosiyivskyi Forest massif. The number of such giant trees older than 300 years is at least a hundred, but now most of them are drying up or on the verge of drying out. Moreover, oak undergrowth is also absent, and nearly all seedlings planted last year have perished. The main reason of decline of historic forests is the significant consolidation of soil along the paths due to excessive recreational pressure. This worsens the water and air regimes of soil and promotes wood extinction. In addition, the well-being of oaks is affected adversely by the following factors: prolonged summer droughts, mass reproduction of oak fleas (Haltica quercetorum Foudr.) and the leaf blotch miner moth (Acrocercops brongniardella Fabricius, 1798), leaves defeated by powdery mildew (Microsphaera alphitoides Griff. et Maubl.), necrotic-cancerous and vascular pathologies, bacteriosis, etc. (Sotnyk, 2018).
Trees growing on the forest periphery closest to the city road network are the most damaged ones.

Holosiyivskyi Forest is surrounded by apartment complexes on all sides: Nauka Prospect, Feofaniya (residential, former mainly park zone), Odesa Square and the Expo Centre. In 2015, on the military unit abandoned territory in Potekhin Street, close to Holosiyivskyi Forest, a huge residential complex of thirteen 27-storey sections named Bergen was aimed to be built. This is precisely the area north of the Holosiyiv stream where the biggest economic and recreational pressure has caused the extinction of almost all rare plants (Parnikoza et al., 2008). If the plans of the developers were implemented, the unique forest ecosystems and the highly valuable Holosiyiv watercourses would have undergone irreversible degradation. Thermal and noise pollution, territory littering and soil compaction due to trampling would have increased dramatically. A substantial increase in the recreational pressure on forest ecosystems, which is now close to critical, would have led to irreversible changes in the natural landscapes.

The planned construction operations presupposed territory asphalting right up to the forest. This would have inevitably led to rainwater discharge directly into the forest landscapes. In turn, this would have contributed to intensification of erosion processes in the loess deposits of the Kyiv Plateau. Automatically, the number of pollution sources would have increased dramatically, and temporary water streams would have transported polluted drainage through the erosion forms from areas adjacent to the Park. Such predictions are confirmed by the perishing of four centenarian oaks due to ravine expansion into Holosiyivskyi Forest where some faculties of the $\mathrm{Na}$ tional University of Life and Environmental Sciences of Ukraine have discharged their rainfall run-off and sewage effluents in defiance of the official ban. Consequently, large-scale development of a huge residential complex and the laying of auxiliary road transport and underground communications close to the forest would have threatened the integrity of the entire Holosiyivskyi massif.

On July 28, 2017, following long time protests of the concerned public, the State Architectural and 
Construction Inspection of Ukraine revoked the permission for the scandalous construction of the Bergen residential complex (INFA, 2017). Now, two years later, in 8 Heroiv Oborony Street, which is very close, another developer is planning a new construction. This time it is a residential complex named Vystavkovyi with five high-rise buildings. The main reason of the entire developers' offensive against unique natural complexes is that Holosiyivskyi NNP still lacks its own land management project. Moreover, the Park's formal boundaries are not defined by any kind of fencing. This creates the risk of permanently losing part of it for development purposes.

\section{Landscape analysis of the Holosiyivskyi} Forest territory

Elevated smoothed and slightly wavy accumulative plains on loess loam with dark-grey, grey, and lightgrey soils under fresh oakeries and suboakeries are spread across most of Holosiyivskyi Forest. Other plots are occupied by slightly wavy and hilly floodplain alluvial terraces with turf podzolic soils under fresh pine and other coniferous forests. Low plains with gley soils under motley grass meadows and flood downgrades with turf gley soils under wet motley grasses formations happen occasionally. Low-lying marsh landscapes with marshy soils under wet woodlands and motley grass are also present.

Landscapes of the broadleaf forest type are predominant. The largest area (156.92 ha) is occupied by wavy deluvial-colluvial slopes with turf and grey forest light loamy soils under fresh suboakeries. Slightly wavy deluvial loamy plains with grey and light-grey light loamy soils under fresh oakery forests are widespread (144.69 ha). Smoothed deluvial plains with grey and light-grey loamy soils under fresh oakeries and suboakeries are distributed across an area of 115.88 ha. Slightly wavy deluvial and colluvial slopes with turf and grey forest sandy light loamy soils under fresh suboakeries occupy an area of 76.87 ha. Smoothed sandy and loamy floodplains with turf gley sandy soils under wet motley grass and wet sedge meadows are less common (74.37 ha). Slightly wavy deluvial sandy slopes with turf weak podzolic sandy soils under complex pinewoods and motley grass formations occupy minor areas (10.92 ha). The Maxym Rylskyi
Holosiyivskyi Park territory is mostly dominated by deluvial loamy plains with grey and light-grey weak gley sandy light loamy soils under fresh oakeries and suboakeries (Fig. 3, Table 2).

With account of the above-described problems, the main drawback of the previous methodological developments in effective management of nature conservation activities in Ukraine is the deficiency or absence of an analysis of the landscape structure of protected areas and its mapping. A landscape map is an information base for all sectoral studies related to species preservation, the flora and fauna value of individual plots, and the determination of their recreational potential and aesthetic attractiveness, etc. The landscape structure should be one of the main criteria for allocating functional zones for such a category of protected areas as the National Park. Functional zoning, conducted on a landscape basis, becomes a landscape functional one. This approach assumes special significance due to the absence of a buffer functional zone (which is not envisaged by legislation) in the current zoning of Holosiyivskyi NNP. Instead, its absence facilitates the dangerous thrusts of developers into the valuable sites of the territory.

\section{Landscape functional zoning of the Holosiyivskyi Forest massif}

This procedure is critical due to the location of Holosiyivskyi Forest within Kyiv limits and the regular occurrence of conflicts between different nature management entities. The LFZ system should provide a differentiated mode of protection, reproduction and use of unique natural complexes not only for Holosiyivskyi Forest but also for the entire Holosiyivskyi NNP. The National Park functional zoning is one of the main stages in the development of its territorial organization project. The procedure includes the following: the allocation of a nature reserved zone and areas of regulated and stationary recreation and an economic zone; the establishment of a territorially differentiated regime of protection, use and reproduction of natural complexes, and biological and landscape diversity; historical and cultural complexes and sites (Legislation, 2014a). Forestry, floristic, faunal, geological-geomorphological and other information is usually used during the allocation of functional 
Fig. 3. Landscape structure of the Holosiyivskyi Forest territory

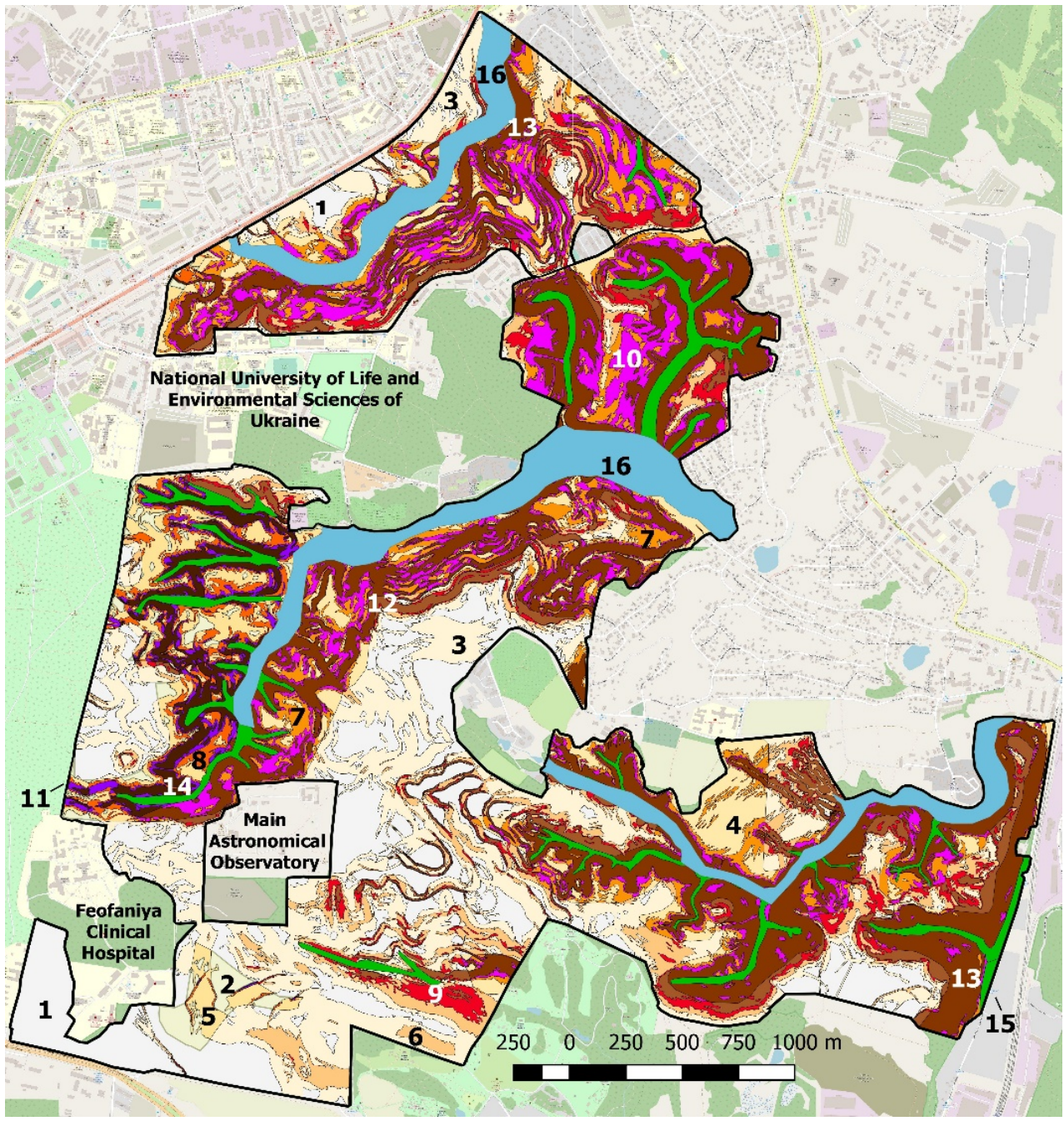

zones. Current functional zoning of Holosiyivskyi NNP is coordinated with all Park land users (Fig. 4).

Functional zoning is performed by superimposing information layers (land categories, recreational value of landscapes, vegetation and forests types, concentration of rare and reference flora and fauna species, the presence of historical and cultural sites, and the recreational and tourist infrastructure) on a cartographic basis (The
Project, unpublished report). However, some problems occurred during the zoning process. They were associated with a lack of information on the localization of rare animal species, as well as an absence of an updated territory landscape map. In this study, the main criterion for allocation of functional zones is the landscape structure of the territory. Using the QGIS toolkit, the LFZ schematic map of the Holosiyivskyi Forest massif was 
Table 2. Landscape complexes in Holosiyivskyi Forest

\begin{tabular}{|c|c|c|}
\hline Map numbering & Landscape complexes & Area, ha/\% \\
\hline 18 & $\begin{array}{l}\text { Smoothed deluvial plains with grey and light-grey loamy soils under fresh oakeries and } \\
\text { suboakeries }\end{array}$ & $115.88 / 12.43$ \\
\hline 2 & $\begin{array}{l}\text { Flat deluvial sandy plains with turf weak podzolic sandy soils under complex pinewoods } \\
\text { and motley grasses formations }\end{array}$ & $11.23 / 1.20$ \\
\hline 3 & $\begin{array}{l}\text { Slightly wavy deluvial plains with grey and light-grey light loamy soils under fresh oakery } \\
\text { forests }\end{array}$ & $144.69 / 15.52$ \\
\hline 4 & $\begin{array}{l}\text { Slightly inclined deluvial and colluvial plains with turf and grey forest sandy light loamy } \\
\text { weakly out washed soils under fresh suboakeries }\end{array}$ & $46.13 / 4.95$ \\
\hline 5 & $\begin{array}{l}\text { Slightly inclined deluvial sandy plains with turf weak podzolic sandy soils under complex } \\
\text { pinewoods and grasses formations }\end{array}$ & $24.12 / 2.59$ \\
\hline 6 & $\begin{array}{l}\text { Acclivous deluvial slopes with grey and light-grey weak gley sandy light loamy soils under } \\
\text { fresh oakeries and suboakeries }\end{array}$ & $65.18 / 6.99$ \\
\hline 7 & $\begin{array}{l}\text { Acclivous deluvial and colluvial slopes with turf and grey forest sandy light loamy weakly } \\
\text { out washed soils under fresh suboakeries }\end{array}$ & $65.25 / 7.00$ \\
\hline 8 & $\begin{array}{l}\text { Acclivous deluvial slopes with turf weak podzolic sandy soils under complex pinewoods } \\
\text { and motley grasses formations }\end{array}$ & $16.13 / 1.73$ \\
\hline 9 & $\begin{array}{l}\text { Slightly wavy deluvial slopes with grey and light-grey weak gley sandy light loamy soils } \\
\text { under fresh oakeries and suboakeries }\end{array}$ & $35.00 / 3.75$ \\
\hline 10 & $\begin{array}{l}\text { Slightly wavy deluvial and colluvial slopes with turf and grey forest sandy light loamy } \\
\text { weakly out washed soils under fresh suboakeries }\end{array}$ & $76.87 / 8.24$ \\
\hline 11 & $\begin{array}{l}\text { Slightly wavy deluvial slopes with turf weak podzolic sandy soils under complex } \\
\text { pinewoods and motley grasses formations }\end{array}$ & $10.92 / 1.17$ \\
\hline 12 & $\begin{array}{l}\text { Wavy deluvial slopes with grey and light-grey weak gley sandy light loamy soils under } \\
\text { fresh oakeries and suboakeries }\end{array}$ & $37.07 / 3.98$ \\
\hline 13 & $\begin{array}{l}\text { Wavy deluvial and colluvial slopes with turf and grey forest sandy light loamy weakly out } \\
\text { washed soils under fresh suboakeries }\end{array}$ & $156.92 / 16.83$ \\
\hline 14 & $\begin{array}{l}\text { Wavy deluvial slopes with turf weak podzolic sandy soils under complex pinewoods and } \\
\text { motley grasses formations }\end{array}$ & $18.18 / 1.95$ \\
\hline 15 & $\begin{array}{l}\text { Bottoms of gullies and ravines in loess and boulder loams with turf gley sandy and light } \\
\text { loamy soils under wet grasses formations, and willow and alder shrubs }\end{array}$ & $34.42 / 3.69$ \\
\hline 16 & $\begin{array}{l}\text { Smoothed sandy and loamy floodplains with turf gley sandy soils under wet motley } \\
\text { grasses and wet sedge meadows }\end{array}$ & $74.37 / 7.98$ \\
\hline Total & & $932.36 / 100$ \\
\hline
\end{tabular}


Fig. 4. Current functional zoning of the Holosiyivskyi Forest massif (according to Schematic map, 2018)

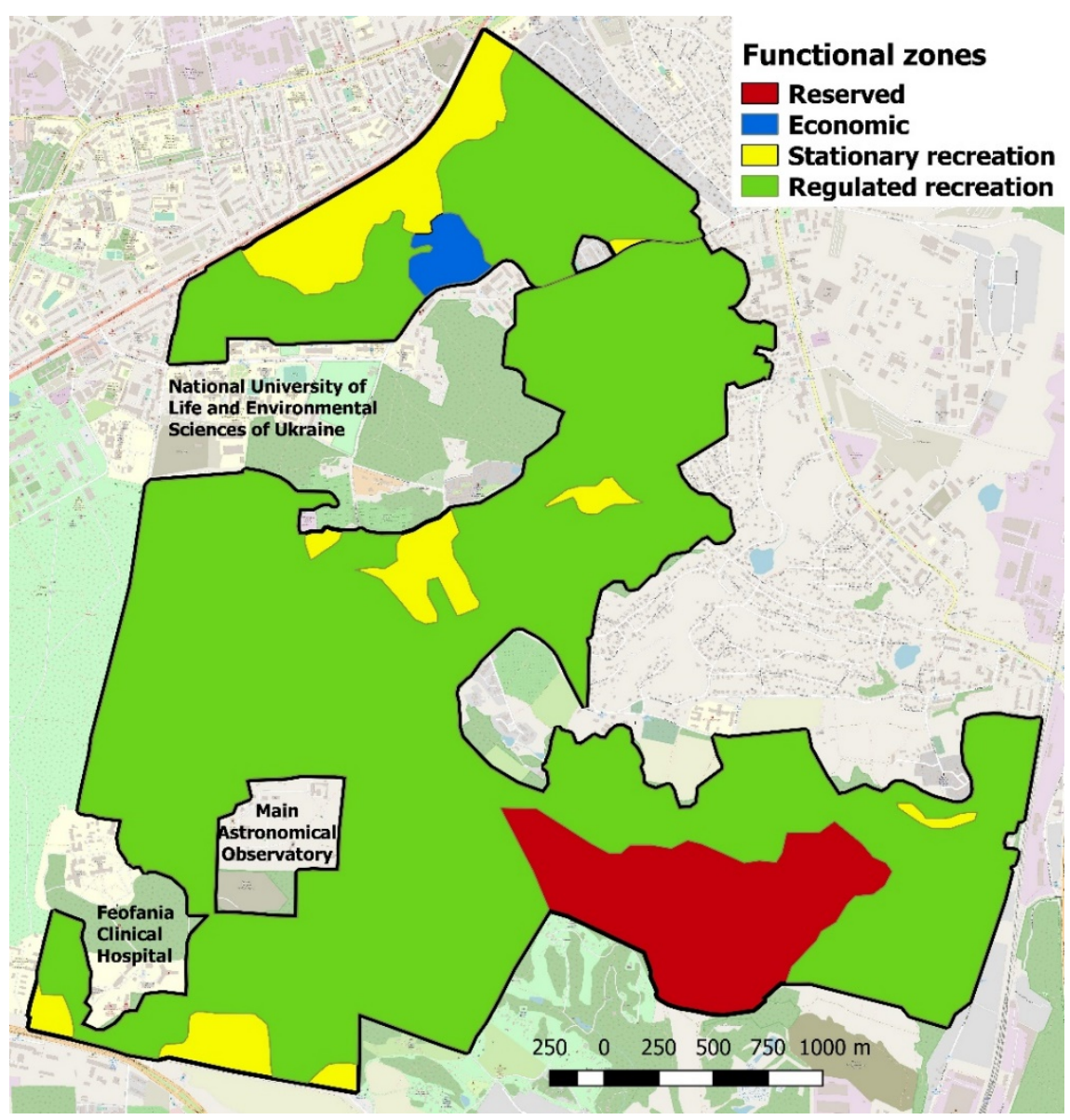

created (Fig. 5). It has specific differences as compared with existing functional zoning.

As seen in Fig. 5, the largest area of the Holosiyivskyi Forest massif (384.98 ha) is the reserved zone (41.29\% of total forest area). It is intended to ensure the preservation of most valuable and unique landscape complexes, the Red Book species populations and their biodiversity. The reserved zone has priority for the functional zoning of any protected area, and its allocation depends on a set of influential factors. Therefore, plots most distant from residential buildings and communication paths, as well as those inaccessible due to terrain features are included in the reserved zone of the Holosiyivskyi Forest massif. For example, the natural core should include areas in the Kytayivskyi ravine headwaters, adjacent to the National Museum of Folk Architecture and Life of Ukraine. Populations of the snowdrop included in the Red Book (Galanthus nivalis L., 1753), which have almost disappeared from other forest ecosystems, are growing here on the slopes. In addition, most of rare animal species living in Holosiyivskyi Forest were found in the reserved core, namely: the smooth snake (Coronella austriaca Laurenti, 1768), the red-footed falcon (Falco vespertinus L., 1766), the forest badger (Meles meles L., 1758), etc. According to Legislation, 
Fig. 5. Landscape functional zoning of the Holosiyivskyi Forest massif

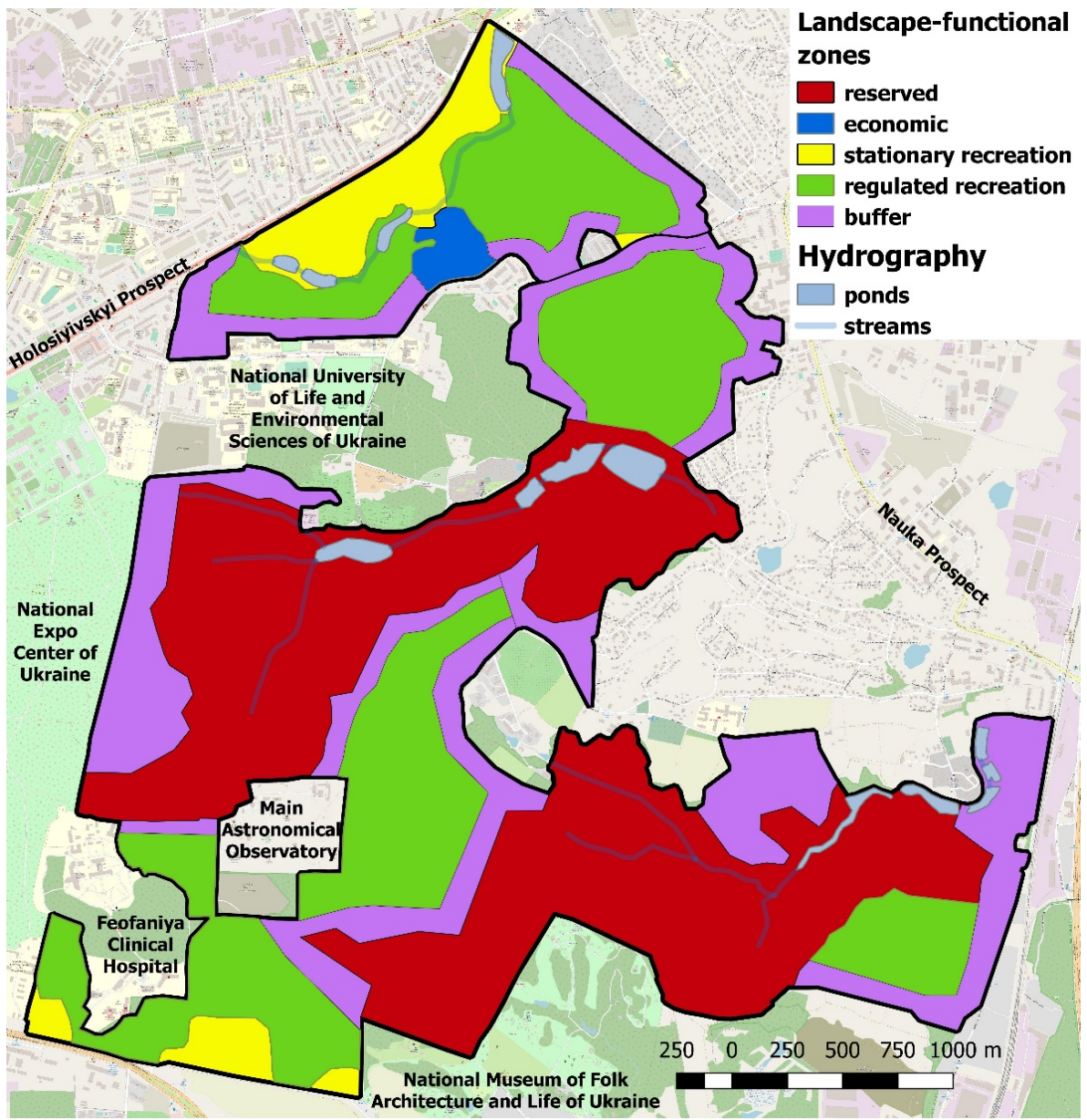

2014a, in the reserved area, it is prohibited to carry out any activity that contradicts the purpose of the zone, violates the course of natural processes or poses a threat of harmful impact on its natural complexes and sites. In particular, it is prohibited to build transport structures and roads, light bonfires, build recreation facilities, fly planes lower than 2,000 $\mathrm{m}$ above the earth surface, conduct geological exploration and damage the topsoil, engage in all kinds of forest use, graze cattle, and go hunting and fishing.

The regulated recreation zone occupies $29.1 \%$ of the Forest territory (271.3 ha). In the controlled recreation zone territory, the following activities are prohibited: principal and severance felling; any construction not related to the NNP activity; mining and destruction of the topsoil; industrial fishing and hunting; transportation and parking; discharge untreated sewage, and any other activities that may have an adverse impact on the landscape and degrade the natural or recreational value of the territory (Legislation, 2014a). This zone includes natural and close to natural areas, which have recreational, eco-educational and scientific and cognitive purposes. Comfortable places for a short rest and walks, combined with a network of tourist routes or ecological trails are arranged here. The stationary recreation zone occupies 55.47 ha $(5.95 \%$ of 
the forest territory) and includes places equipped for prolonged leisure of the public. It is desirable that this zone will not border on valuable natural complexes. Besides, the stationary recreation zone should include areas with a huge influx of visitors.

The economic zone is the smallest one and occupies only 8.97 ha (0.96\% of the forest territory). It includes water treatment facilities, a greenhouse complex and the administration of the Maxym Rylskyi Holosiyivskyi Park. In the stationary recreation zone and the utility zone, any activity that can lead to deterioration of the environment and degrade the territory recreational value is also prohibited (Legislation, 2014a). The developed LFZ scheme provides for a buffer zone or a zone of potential renaturalization of landscapes. A functional buffer zone is "a multifunctional area peripheral to a sensitive site, which is landscaped or managed to enhance positive impacts of development and reduce its adverse ones" (Profit, 2015, p. 3). The principles of creating a buffer landscape functional zone (BLFZ) in Holosiyivskyi Forest conform to its landscape structure and the functions to be performed. The basic BLFZ functions are as follows: protecting natural habitats, keeping out invasive species, preserving biodiversity, preventing contamination and accumulation of waste, and providing public with ecosystem services. The main purpose of the BLFZ over almost the entire forest perimeter is to minimize ecological conflicts arising due to different urban life activities. However, creating a BLFZ has its special aspects in different parts of the forest.

In the northern part of Holosiyivskyi Forest, the BLFZ landscape structure is dominated by gentle slopes covered with fresh suboakeries on turf and grey forest soils. The biggest threat to forest ecosystems is the ingress of pollutants and domestic waste into the regulated recreation zone that borders on the BLFZ. The close proximity of residential blocks brings the recreational flow mainly to the BLFZ. Accordingly, this will reduce the recreation pressure on the landscape zones of regulated recreation and, in the future, will facilitate the restoration there of the soil and vegetative cover. Blakytnoho Street, which separates the northern part of Holosiyivskyi Forest from the rest of the massif, has intense automotive traffic, and so it is surrounded with a BLFZ on both sides (Fig. 6). Its function is to minimise transport pollution and prevent the ingress of heavy metals into the recreation zone. The main guiding principle for the establishment of BLFZ in the northern part of the forest is to restrain contamination, pollution and recreational flows from outside.

On the western perimeter of the central part of Holosiyivskyi Forest, the BLFZ features gently sloping and flat plain forest landscapes. Its allotment is associated with the immediate neighbourhood of the forest reserved zone with the national Expo Centre of Ukraine and city residential blocks (Fig. 7). Hence, a BLFZ here is required to protect the habitats of rare flora and fauna species from potential development and noise pollution, and to counteract the entry of invasive species to the reserved zone. The southeastern peripheral buffer zone of Holosiyivskyi Forest borders on the reserved zone and partially - on the regulated recreation zone. The landscape structure is dominated with hard-to-reach wooded slopes dissected with gullies and ravines not adapted for recreation activities. Private estates are located very close to the ecosystems of the reserved zone. Therefore, the BLFZ will restrain the discharge of polluted waste directly into the forest landscapes, thus preventing the activation of erosion processes (Fig. 8). The governing principle of creating a BLFZ around the regulated recreation zone in this part of Holosiyivskyi Forest is the preservation of ecosystem services, predominantly soil protection, wellness and cultural-historical ones. These services are vital for the visitors of the forest and the adjacent National Museum of Folk Architecture and Life of Ukraine.

The BLFZ in the middle of the Holosiyivskyi Forest massif performs an ecotone function - gradual transition from sloping landscapes of the reserve core to plain landscape complexes in the regulated recreation zone. Within BLFZ limits, active interaction takes place between matter-and-energy flows of transitional vegetative groups and fauna complexes. Yet another function of this BLFZ is to prevent loss of the forest biotopes biodiversity in the reserved zone due to recreation activities on weekends and holidays (Fig. 9). The total area of the BLFZ in Holosiyivskyi Forest is 211.62 
ha $(22.7 \%)$, this being sufficient to perform protection and mitigation functions. The LFZ carried out in this way will contribute to optimizing nature conservation and the recreational functions of the National Natural Park. This means that requisite measures will be planned in a coordinated manner to form a unified system.

\section{Conclusions}

Research conducted in one of the massifs of Holosiyivskyi NNP confirmed an extraordinary anthropogenic pressure on the unique natural complexes by the urban environment of Kyiv. In order to regulate the recreational and other adverse impacts on the Holosiyivskyi Forest massif, landscape analysis of its territory was conducted, and functional zoning was transferred to a landscape basis. Holosiyivskyi Forest territory differentiation is updated according to the created landscape map in the form of an LFZ scheme. The boundaries and sizes of each zone are based on

Fig. 6. Road in the northern part of Holosiyivskyi forest

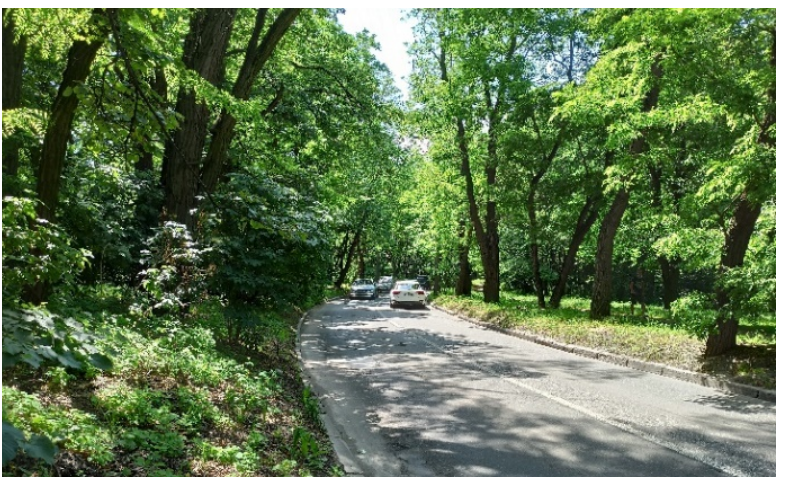

Fig. 8. Littering in the regulated recreation zone

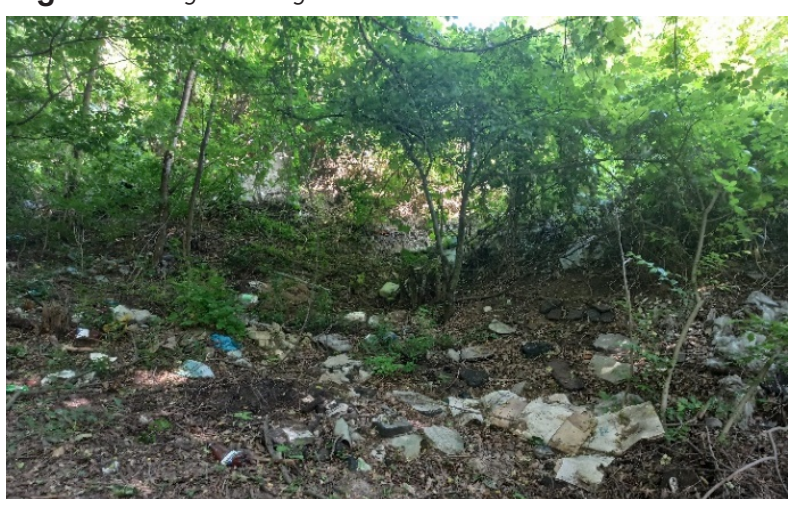

the territory landscape structure, considering nature conservation and the scientific, recreational, historical, cultural and other values of the natural complexes being studied.

A fundamental novelty of this zoning is the application of a landscape approach and the allocation of a buffer zone, which is not provided by Ukrainian legislation. Instead, it will avoid the emergence of unauthorized dumps, new construction sites, activation of erosion processes, soil and vegetation damage, and the dwindling and loss of many species in areas adjacent to the Park. Moreover, adding a buffer zone will require to expand the National Park territory, which fully corresponds to the key points in the draft General Plan of Kiev (Master Plan, 2015, p. 56). The study findings serve as a basis for minimizing existing nature management conflicts, reducing anthropogenic impact on the Holosiyivskyi Forest ecosystems, optimal management of recreational flows, as well as for planning anti-erosion and other measures to optimize the functioning of protected areas in an urbanized environment.

Fig. 7. Residential neighbourhoods near the reserved zone

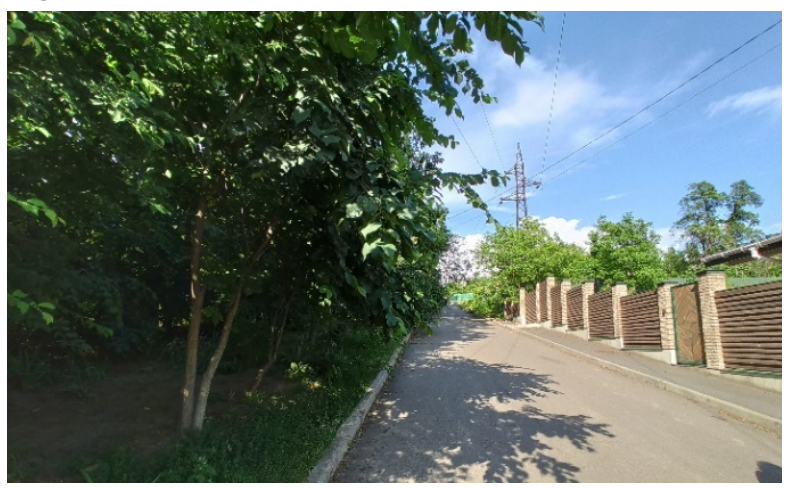

Fig. 9. Degradation of the forest ecosystems in the reserved zone

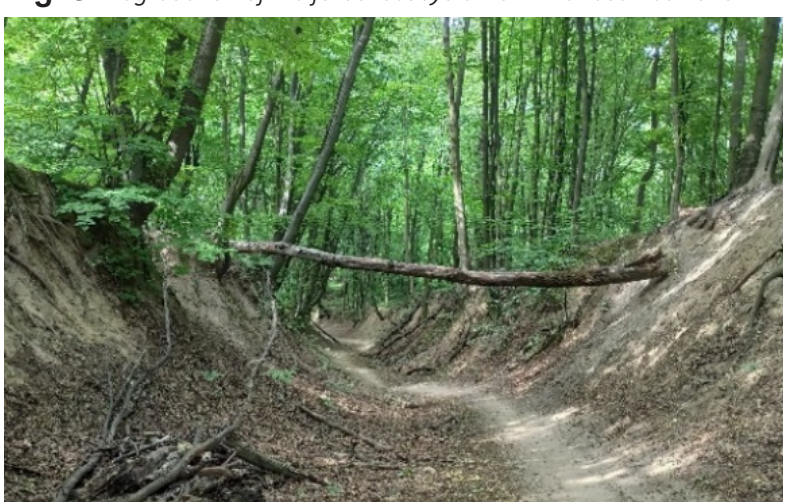




\section{References}

Deveikienè V. (2018) Methodological guidelines for optimizing the interaction between landscape architecture and urban planning. Scientific Journal of Latvia University of Life Sciences and Technologies Landscape Architecture and Art 12(12): 7-21. https://doi.org/10.22616/j.landarchart.2018.12.01

Filozof R. S. (2010) Mapping geoinformation support for the creation of regional landscape parks (on the example of RLP "Holosiyiv"). Ph.D. thesis. Kyiv Taras Shevchenko National University, Kyiv, 20 р. (in Ukrainian) [Філозоф Р.C. Картографічне геоінформаційне забезпечення створення регіональних ландшафтних парків (на прикладі РлП "Голосіїв"). Автореферат дисертації на здобуття наукового ступеня кандидата географічних наук. К., 2010. 20 с.]

Haifeng L., Wenbo C. and Wei H. (2015) Planning of Green Space Ecological Network in Urban Areas: An Example of Nanchang, China. International Journal of Environmental Research and Public Health 12(10): 12889-12904. https://doi.org/10.3390/ ijerph121012889

Hasti F., Rouhi H., Khodakarami l., et al. (2016) Zoning the protected area of Shahoo/Kosalan using RS and GIS. Journal of Environmental Science, Toxicology and Food Technology 8(I): 74-81. https://doi.org/10.9790/2402-1008017481

Havrylenko O.P., Tsyhanok Ye.Yu. (2018) Landscape analysis for the optimization of nature protection management in the urbanized environment. Ukrainian Geographical Journal 1(101): 24-29. (in Ukrainian) [Гавриленко О.П., Циганок Є.Ю. Ландшафтознавчий аналіз для оптимізації природоохоронногоприродокористуваннявурбанізованому середовищі. Український географічний журнал. 2018, 1(101): 24-29.]. https://doi.org/10.15407/ugz2018.01.024

INFA (Information Accent) (2017) Kievans have achieved the abolition of permission to scandalous construction near the Holosiyivskyi forest (in Ukrainian) [Кияни домоглися скасування дозволу на скандальне будівництво біля Голосіївського лісу.] Available at: https://www.infa.ua/ky-yany-domogly-sya-skasuvannya-dozvolu-na-skandal-ne-budivny-tstvo-bilya-golosiyivs-kogo-lisu/\# (accessed 18 September 2019).

Khoshtaria T.K., Chachava N.T. (2017) The planning of urban green areas and its protective importance in resort cities (case of Georgian resorts). Annals of Agrarian Science 15: 217-223. https://doi.org/10.1016/j.aasci.2017.05.009

Legislation of Ukraine (2008) On creation of the National Natural Park «Holosiyivskyi». Decree of the President of Ukraine \# 794/2007, ed. 15.11.2008 (in Ukrainian) [Про створення національного природного парку "Голосіївський". Указ Президента України № 794/2007, ред. від 15.11.2008.] Avail- able at: https://zakon.rada.gov.ua/laws/show/794/2007 (accessed 20 September 2019).

Legislation of Ukraine (2014a) Regulations about the project of organization of the national natural park territory, protection, reproduction and recreational use of its natural complexes and objects. Order dated August 21, 2014, No. 273 (in Ukrainian) [Положення про проект організації території національного природного парку, охорони, відтворення та рекреаційного використання його природних комплексів і об'єктів. Наказ від 21.08.2014 № 273.] Available at: https://zakon.rada.gov.ua/ laws/show/z0831-05 (accessed 20 September 2019).

Legislation of Ukraine (2014b) About the change of boundaries of the National Natural Park «Holosiyivskyi». Decree of the President of Ukraine \# 446/2014 dated 01.05.2014 (in Ukrainian) [Про зміну меж національного природного парку "Голосіївський". Указ Президента України № 446/2014 від 01.05.2014.] Available at: https://zakon.rada.gov.ua/laws/ show/446/2014 (accessed 20 September 2019).

Marynych O.M., Parhomenko H.O., Petrenko O.M., et al. (2003) Improved physical-geographical zoning of the Ukraine. Ukrainian Geographical Journal 1: 16-20. (in Ukrainian) [Маринич О.М., Пархоменко Г.О., Петренко О.М. та ін. Удосконалена схема фізико-географічного районування України. Український географічний журнал. 2003, 1: 16-20.]

Master Plan of Kyiv. Basic provisions (2015) (in Ukrainian) [Генеральний план м. Києва, 2015. Основні положення.] Available at: https://drive.google.com/file/d/OBxbGBoNdb1j6TTRuS3RMQjFINTA/view (accessed 20 September 2019).

National Natural Park "Holosiyivskyi" (2018) Territorial structure (in Ukrainian) [Територіальна структура]. Available at: http:// nppg.gov.ua/uk/ter-structure (accessed 15 September 2019).

Onyshchenko V.A., Prjadko O.I., Virchenko V.M., et al. (2016) Vascular plants and bryophytes of Holosiyivskyi National Nature Park (in Ukrainian). Kyiv, Ukraine: Alterpress, 94 p. (in Ukrainian) [Онищенко В.А., Прядко О.І., Вірченко В.М. та ін. Судинні рослини і мохоподібні національного природного парку "Голосіївський". Київ, Україна: Альтерпрес, 2016, 94 с.] Available at: http://www.botany.kiev.ua/doc/sud_rosl_moh. pdf (accessed 16 September 2019).

Parnikoza I.Ju., Shevchenko M.S. and Petrenko N.A. (2008) The current state of rare plants populations of Holosiyivskyi forest in Kyiv Actual problems of botany and ecology 2: 105-115. (in Ukrainian) [Парнікоза І.Ю., Шевченко М.С., Петренко Н.А. Сучасний стан популяцій рідкісних рослин Голосіївського лісу в м. Києві. Актуальні проблеми ботаніки та екології. 2008. Вип. 2. С. 105-115.] 
Profit M. (2015) Functional Buffer Zone: Best practice to protect sensitive sites. Available at: https://cumbernauldlivinglandscape. org.uk/docs/083_385_functionalbufferzoneguidance_marionprofit2016_1455633047.pdf (accessed 12 September 2019).

Project of organization of the National Natural Park «Holosiyivskyi» territory, protection, reproduction and recreational use of its natural complexes and objects (2013) (unpublished Report, in Ukrainian) [Проект організації території національного природного парку "Голосіївський", охорони, відтворення та рекреаційного використання його природних комплексів і об'єктів.]

Ruiz-Labourdette D., Schmitz M.F., Montes C., et al. (2010) Zoning a Protected Area: Proposal Based on a Multi-thematic Approach and Final Decision. Environmental Modelling and Assessment 15: 531-547. https://doi.org/10.1007/s10666-010-9223-5

Schematic map of functional zoning of NPP "Holosiyivskyi" (2018) (in Ukrainian) [Картосхема функціонального зонування НПП "Голосіївський".] Available at: http://nppg.gov.ua/uk/ node/58 (accessed 10 September 2019).
Sotnyk L.P. (2018) Phytopathological studies of oak tree stands on the territory of NPP "Holosiyivskyi" in the conditions of the transformed environment. In: Proceedings of the 2nd International Scientific and Practical Conference "Problems of Ecology and Evolution of Ecosystems in Conditions of the Transformed Environment", Chernihiv, Ukraine, 11-12 March 2018, pp. 123126 (in Ukrainian). [Сотник Л.П. Фітопатологічні дослідження дубових деревостанів на території НПП "Голосіївський" в умовах трансформованого середовища. Матеріали ॥ Міжнародної науково-практичної конференції "Проблеми екології та еволюції екосистем в умовах трансформованого середовища", Чернігів, 11-12 жовтня 2018 р. С. 123-126.]

Trzyna T. (2014) Urban Protected Areas: Profiles and best practice guidelines. Best Practice Protected Area Guidelines Series, 22. Available at: https://portals.iucn.org/library/sites/library/ files/documents/PAG-022.pdf (accessed 12 September 2019).

Veinberga M., Zigmunde D. (2016) Aesthetics and Ecology in Planning of Urban Green Spaces of Latvia. Scientific Journal of Latvia University of Agriculture 8(8): 43-52. 